\title{
Comparative Bioavailability Evaluation of Erythromycin Base and Its Salts and Esters. I. Erythromycin Estolate Capsules Versus Enteric-Coated Erythromycin Base Tablets
}

A. R. DisANTO, Ph.D., K. Y. TSERNG, Ph.D., D. J. CHODOS, M.D. K. A. DasANTE, Ph.D., K. S. ALEERT, Ph.D., and J. G. WAGNER, Ph.D. Kalamazoo, Mich., and Ann Arbor, Mich.

$\mathrm{E}_{\text {Rythromycin estolate, the lauryl sul- }}$ $\perp_{\text {fate salt of erythromycin 2-propio- }}$ nate, has an advantage over erythromycin base and erythromycin stearate in being acid stable. After its introduction about 20 years ago, erythromycin estolate became widely popular. Using conventional methods of microbiologic assay, researchers found that oral administration of the estolate produced higher total blood levels of erythromycin than did enteric-coated erythromycin or propionyl erythromycin and that food intake did not affect these levels. ${ }^{1-8}$ It was presumed that the apparent superiority of absorption of the propionate was the only reason for these higher levels, but the assays used did not discriminate between the bioactive and bioinactive portion of plasma erythromycin.

In 1962, Griffith and Black ${ }^{9}$ showed that similar peak blood levels resulted from oral administration of a single 250 . mg dose of either erythromycin stearate or erythromycin base protected by an acid-resistant coating; however, administration of $250 \mathrm{mg}$ erythromycin estolate resulted in levels almost four times those obtained with the same dose of the base or stearate salt. In 1964, Griffith and

From The Upjohn Company, Kalamazoo, Mich. 49001, and the College of Pharmacy, The University of Michigan, Ann Arbor, Mich. 48104.
Black $^{10}$ reported similar results from a single- and multiple-dose study comparing erythromycin estolate and erythromycin stearate; blood levels of the estolate compared with those of the stearate were at least twice as high in the fasting state and more than 10 times higher in the nonfasting state. In 1967, Bell11 found that erythromycin estolate produced higher blood levels than did an enteric-coated preparation. (He also reported later, in 1971, that serum levels after administration of the estolate in the nonfasting state were 14 times those obtained after the same dose of the stearate. ${ }^{12}$ )

It became evident, however, that only a small proportion of erythromycin propionate was hydrolyzed in the bloodstream after administration of erythromycin estolate. Neaverson ${ }^{13}$ found in 1968 that the ratio of free erythromycin to erythromycin propionate in the blood was about 1:9. Using a different chromatographic procedure, Stephens et al. ${ }^{14}$ showed that the proportion of free base was about 20 to 35 per cent of the total antibiotic present in the blood. By 1969, investigators were generally agreed that erythromycin propionate is microbiologically inactive per se and must be hydrolyzed to its free base in order to exert its antimicrobial action. ${ }^{15}$ 
The present study compares the plasma concentrations of erythromycin base after oral administration of erythromycin estolate and enteric-coated erythromycin base, using a newly developed chemical method that discriminates between plasma concentrations of erythromycin propionate and erythromycin base. ${ }^{16}$

\section{Materials and Methods}

\section{Subjects}

Selected for the study were 16 normal, healthy adult volunteers: six female (average age, 23.5 years; average weight, 141.5 pounds) and 10 male (average age, 20.7 years; average weight, 162.1 pounds). All were nonobese as determined by the criteria of Desirable Weights of Adults ${ }^{17}$ and had received no antibacterial medication for 15 days, no long-acting antibacterial drug for 30 days, and no other medication for seven days before the start of the study. Temperature, pulse, respiration, blood pressure, and selected laboratory parameters including hematologic findings, urinalysis, blood urea nitrogen, serum alkaline phosphatase, serum glutamic-oxaloacetic transaminase, serum bilirubin, and glucose all had to be within normal range.

\section{Procedure}

Subjects were given either a 250-mg tablet of enteric-coated erythromycin* or a 250-mg capsule of erythromycin estolate** every 6 hours, with at least a 2 hour fast before and after drug administration, for a total of 12 consecutive doses. They drank 6 ounces water with each dose.

A completely randomized two-way crossover design was utilized, with seven

"E-Mycin, The Upjohn Company, Kalamaroo, Mich. 49001, Lot Number 381CE, potency 262 mg.

** Mosone, Dista Products Company, Indianapolis, Ind. 46206, Lot Number 7FJ75A, potency 259 mg. days separating the initial medication days for the two treatment periods. The subjects were confined the night before the study started and for the entire 84 hours of each treatment period. They received standardized meals, ingesting each within a 30-minute interval. The schedule for meals and medication was as follows: minus 2.5 hours, breakfast; 0 hours, dose \#1; 3.5 hours, lunch; 6 hours, dose \#2; 8.5 hours, dinner; 12 hours, dose \# 3; 15.5 hours, snack; 18 hours, dose \# 4 ; 21.5 hours, breakfast; 24 hours, dose \#5. This pattern was repeated until the administration of dose \#12 at 66 hours.

Subjects were permitted to smoke but not to engage in any strenuous or athletic activities during the days of or on the day following drug administration. Blood samples were drawn from each subject at 1.5-hour intervals during the first 12 hours of day 1 (0-12 hours after the first dose), every 1.5 hours on day 3 (48-72 hours after the first dose), and every 4 hours thereafter until the 84th hour. This allowed for sampling of the last dose up to 18 hours after administration. Plasma was harvested from all blood samples right after drawing and was frozen im. mediately.

\section{Analysis of Plasma Samples}

Investigators analyzed erythromycin in the plasma samples by the method of Tserng and Wagner. ${ }^{16}$ Since hydrolysis of propionyl erythromycin is appreciably slower in the frozen state than in solution, appropriate corrections were made for continued hydrolysis. Plasma levels of erythromycin base and erythromycin propionate were measured separately in each sample from all subjects who received erythromycin estolate. The total erythromycin plasma level is defined as the sum of the levels of base and propionate.

The Journal of Clinical Pharmacology 


\section{Analysis of Data}

Data were analyzed according to the standard analysis of variance for equally replicated rows of a Latin square with equal group sizes.

\section{Results}

\section{Comparison of Total Erythromycin Levels}

As anticipated, total erythromycin levels (erythromycin base plus erythromycin propionate) after administration of erythromycin estolate capsules were at least three times higher than those after administration of erythromycin enteric-coated tablets. The average plasma erythromycin and total erythromycin concentration-time profiles obtained with both treatments are presented in Fig. 1. A comparison of the plasma total erythromycin levels at each sampling time and parameters of maximum concentration, minimum concentration, and area under the plasma concentration-time curve tested significantly different $(P<0.001)$ for the two preparations. These findings are in agreement with earlier studies which used microbiological assay. ${ }^{10,11}$

\section{Comparison of Erythromycin Plasma Levels}

After three days of oral administration of erythromycin estolate, the per cent hydrolysis of erythromycin propionate to erythromycin base averages about 24 per cent, ranging from a low of 16 per cent 3 hours after the first dose to a high of 43 per cent 18 hours after administration of the $12 \mathrm{th}$, or last, dose. (The 43 per cent figure is probably due to assay insensitivity at the low concentrations occurring 18 hours after the last dose.) Disregarding the data beyond 72 hours, the range in hydrolysis would vary from the 16 per cent low (occurring 3 hours after the first dose) to a high of 27 per cent, which occurred at $6,55.5,66$, and 72 hours after drug administration.

As illustrated in Fig. 1, there were minimal differences in the amount of bioactive plasma erythromycin after inges.

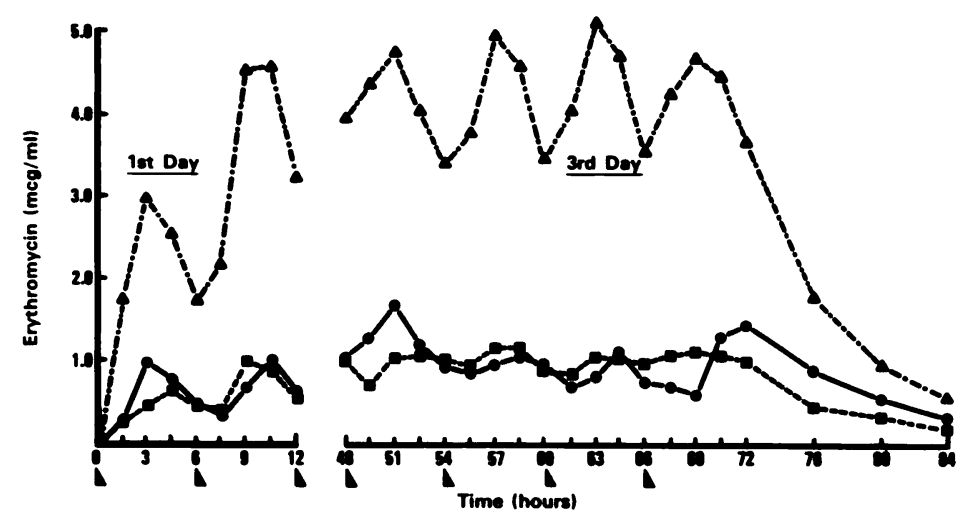

Fig. 1. Average plasma erythromycin concentrations (in $\mu g / m l$ ) from 16 healthy subjects after $12250-\mathrm{mg}$ doses of erythromycin entericcoated tablets or erythromycin estolate capsules, given every 6 hours with a 2-hour fast before and after: (๑) erythromycin enteric-coated tablet (Lot \#381CE); (घ) erythromycin estolate capsule (Lot \#7FJ75A); ( $\Delta$ ) erythromycin estolate capsule (Lot \#7FJ75A) as total erythromycin; (N) drug administered. 
DISANTO, TSERNG, CHODOS, ET $A L$.

TABLE I

Multiple-Dose Bioavailability Parameters Obtained for 16 Normal Adults Following Oral Administration of 12 Consecutive Doses of $250 \mathrm{mg}$ Erythromycin in a Multiple-Dose Regimen*

\begin{tabular}{|c|c|c|c|c|}
\hline & $\begin{array}{l}\text { Dosing } \\
\text { interval } \\
(\mathrm{hr})\end{array}$ & $\begin{array}{l}\text { Erythromycin } \\
\text { enteric-coated } \\
\text { tablet }\end{array}$ & $\begin{array}{l}\text { Erythromycin } \\
\text { estolate } \\
\text { capsule }\end{array}$ & $\begin{array}{l}\text { Statistical } \\
\text { significance } \\
\text { (ANOVA) }\end{array}$ \\
\hline & \multicolumn{4}{|c|}{ 1st Day (0-12 Hours; 1st-2nd Doses) } \\
\hline $\begin{array}{l}\text { Average of the individual } \\
\text { maximum serum concentration } \\
(\mu \mathrm{g} / \mathrm{ml}) \text { at }\end{array}$ & $\begin{array}{l}0-6 \\
6-12\end{array}$ & $\begin{array}{l}1.17 \\
1.34\end{array}$ & $\begin{array}{l}0.73 \\
1.27\end{array}$ & $\underset{\text { n.s. }}{P<0.05}$ \\
\hline $\begin{array}{l}\text { Average of the individual } \\
\text { minimum serum concentration } \\
(\mu \mathrm{g} / \mathrm{ml}) \text { at }\end{array}$ & $6-12$ & .21 & .32 & n.s. \\
\hline \multirow[t]{2}{*}{$\begin{array}{l}\text { Average of areas under } \\
\text { individual serum concentration- } \\
\text { time curves }(\mu \mathrm{g} \cdot \mathrm{hr} / \mathrm{ml}) \text { at }\end{array}$} & $\begin{array}{l}0-6 \\
6-12 \\
0-12\end{array}$ & $\begin{array}{l}3.50 \\
3.98 \\
7.48\end{array}$ & $\begin{array}{l}2.49 \\
4.27 \\
6.76\end{array}$ & $\begin{array}{l}P<0.05 \\
\text { n.s. } \\
\text { n.s. }\end{array}$ \\
\hline & \multicolumn{4}{|c|}{ 3rd Day (48-84 Hours; 9th-12th Doses) } \\
\hline $\begin{array}{l}\text { Average of the individual } \\
\text { maximum serum concentration } \\
(\mu \mathrm{g} / \mathrm{ml}) \text { at }\end{array}$ & $\begin{array}{l}48-54 \\
54-60 \\
60-66 \\
66-72 \\
66-84\end{array}$ & $\begin{array}{l}1.89 \\
1.40 \\
1.32 \\
1.86 \\
2.08\end{array}$ & \begin{tabular}{l|}
1.36 \\
1.37 \\
1.21 \\
1.36 \\
1.38
\end{tabular} & $\begin{array}{c}P<0.025 \\
\quad \text { n.s. } \\
\text { n.s. } \\
\text { n.s. } \\
P<0.05\end{array}$ \\
\hline $\begin{array}{l}\text { Average of the individual } \\
\text { minimum serum concentration } \\
(\mu \mathrm{g} / \mathrm{ml}) \text { at }\end{array}$ & $\begin{array}{l}48-54 \\
54-60 \\
60-66 \\
66-72 \\
66-84\end{array}$ & $\begin{array}{l}0.68 \\
0.54 \\
0.48 \\
0.34 \\
0.20\end{array}$ & $\begin{array}{l}0.57 \\
0.70 \\
0.70 \\
0.75 \\
0.16\end{array}$ & $\begin{array}{c}\text { n.s. } \\
\text { n.s. } \\
P<0.025 \\
P<0.005 \\
\text { n.s. }\end{array}$ \\
\hline $\begin{array}{l}\text { Average of areas under } \\
\text { individual serum concentration- } \\
\text { time curves }(\mu \mathrm{g} \cdot \mathrm{hr} / \mathrm{ml}) \text { at }\end{array}$ & $\begin{array}{l}48-54 \\
54-60 \\
60-66 \\
66-72 \\
66-84 \\
48-72 \\
48-84\end{array}$ & \begin{tabular}{r|}
7.67 \\
5.67 \\
5.20 \\
5.55 \\
14.81 \\
24.10 \\
33.36
\end{tabular} & $\begin{array}{r}5.61 \\
6.25 \\
5.66 \\
6.30 \\
11.68 \\
23.83 \\
29.21\end{array}$ & $\begin{array}{c}P<0.025 \\
\text { n.s. } \\
\text { n.s. } \\
\text { n.s. } \\
\text { n.s. } \\
\text { n.s. } \\
\text { n.s. }\end{array}$ \\
\hline
\end{tabular}

- Erythromycin base, 250-mg enteric-coated tablet; or erythromycin estolate, 250-mg capsule.

tion of either erythromycin base entericcoated tablets or erythromycin estolate capsules. Of the 28 average plasma erythromycin concentration values obtained, six showed significant differences $(P<0.05$ or better $)$ in base concentra- tions for the two treatments, with higher levels generated by the enteric-coated tablets at $3,49.5,51,80$, and 84 hours and by the estolate capsules at 69 hours.

Table I lists for each dosing interval the average maximum and minimum con- 


\section{BIOAVAILABILITY OF ERYTHROMYCIN.}

centrations and areas under the concentration-time curve ( $A U C \mathrm{~s})$. The average erythromycin $A U C$ during 0 to 12 hours on the first day of drug administration was $7.48 \mu \mathrm{g} \cdot \mathrm{hr} / \mathrm{ml}$ for erythromycin enteric-coated tablets and $6.76 \mu \mathrm{g} \cdot \mathrm{hr} / \mathrm{ml}$ for the erythromycin estolate capsules. The area generated during 48 to 72 hours (day 3) was $24.1 \mu \mathrm{g} \cdot \mathrm{hr} / \mathrm{ml}$ for the tablets and $23.83 \mu \mathrm{g} \cdot \mathrm{hr} / \mathrm{ml}$ for the capsules.

Averages of the individual maximum erythromycin plasma concentrations occurring during all dosing intervals were higher with erythromycin base entericcoated tablets than with erythromycin estolate capsules. At 0 to 6 hours and 6 to 12 hours, the average maximum concentrations, in $\mu \mathrm{g} / \mathrm{ml}$, with the base tablets were 1.17 and 1.34, respectively; during the same intervals, the estolate capsules gave average maximum concentrations of 0.73 and $1.27 \mu \mathrm{g} / \mathrm{ml}$, respectively. On day 3, maximum concentrations between 48 and 54 hours and 66 and 84 hours were 1.89 and $2.08 \mu \mathrm{g} / \mathrm{ml}$, respectively, for the erythromycin enteric-coated tablets and 1.36 and $1.38 \mu \mathrm{g} / \mathrm{ml}$, respec- tively, for the erythromycin estolate capsules. These differences were statistically significant.

Averages of the individual minimum concentrations tended to be slightly lower with the enteric-coated tablets than with the estolate capsules. However, the differences were not statistically significant except after the third and fourth doses on day 3 , when minimum concentrations were 0.48 and $0.34 \mu \mathrm{g} / \mathrm{ml}$, respectively, for the tablets, compared with 0.70 and $0.75 \mu \mathrm{g} / \mathrm{ml}$, respectively, for the capsules.

Figure 2 delineates for each form of the drug the percentage of plasma samples found to contain specific concentrations of erythromycin base during the four steady-state dosage intervals from 48 to 72 hours. As this histogram shows, there are minimal differences between the levels obtained with tablets or capsules.

\section{Discussion}

In the early 1960 s, investigators ${ }^{18,19}$ showed by means of a microbiologic assay method employing Sarcina lutea that serum levels of total erythromycin after

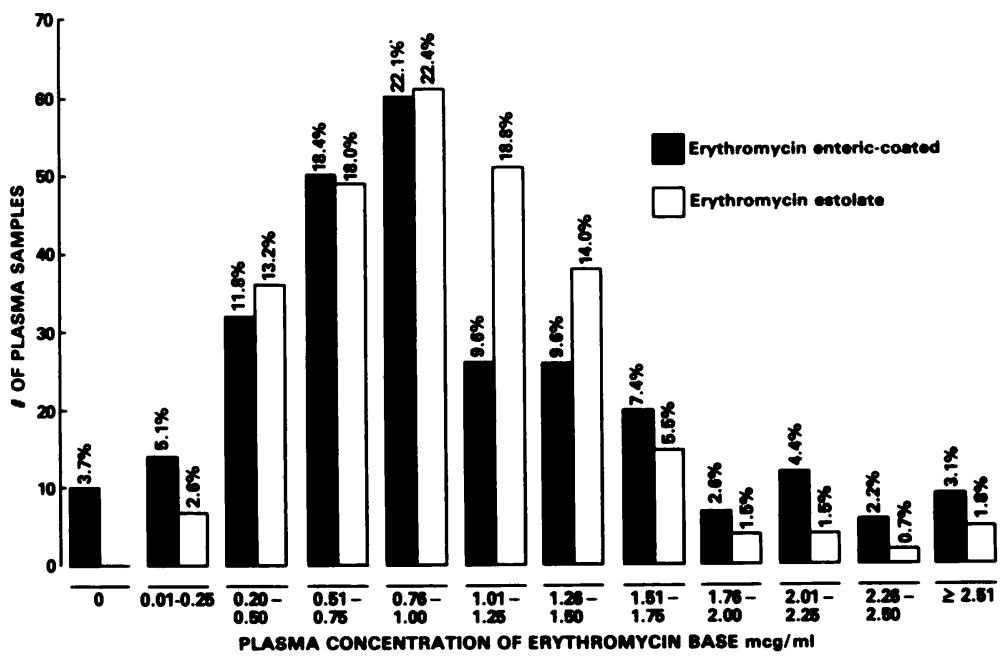

Fig. 2. Percentage of plasma samples with specific concentrations of erythromycin base during four steady-state dosage intervals (48-72 hours) after administration of 250-mg doses given every 6 hours: (घ) erythromycin enteric-coated; (ㅁ) erythromycin estolate. 
administration of erythromycin estolate are superior to those obtained with erythromycin. Later, Tserng and Wagner ${ }^{16}$ discussed factors that must be considered in evaluating serum concentrations of erythromycin by microbiologic assay. Stephens et al., ${ }^{15}$ using paper chromatography, had shown in 1969 that the major circulating species after administration of erythromycin estolate was erythromycin propionate, with whole blood, serum, plasma, and urine containing 20 to 25 per cent erythromycin and 75 to 80 per cent erythromycin propionate. The results of the present study agree quite well with these findings.

Apparently, 75 per cent of the erythromycin propionate is hydrolyzed to bioactive erythromycin base during the microbiologic assay process itself. In this study it also has been shown that the per cent total erythromycin propionate hydrolyzed to erythromycin is relatively constant from dose to dose. Bechtol and co-workers ${ }^{21}$ did not find this consistency in in vivo hydrolysis; they reported that erythromycin propionate undergoes more hydrolysis after multiple doses than after a single dose. (Their results showing an increase in hydrolysis on continued dosing was probably due to methodologic errors which they reported.)

Although the efficiency of gastrointestinal absorption of erythromycin propionate is apparently greater than that of erythromycin, the results of this study show that there is essentially no difference in the circulating levels of bioactive erythromycin base after administration of either enteric-coated base tablets or estolate capsules.

\section{Bummary}

A randomized crossover study in 16 healthy volunteers given multiple doses of erythromycin base enteric-coated tablets or erythromycin estolate capsules revealed essentially no difference in the resultant plasma concentration of bioactive erythromycin. This similarity in bioactivity persisted despite the fact that total erythromycin levels (bioactive erythromycin base plus bioinactive erythromycin propionate) were at least three times higher after administration of the estolate than after administration of the base.

\section{Acknowledgment}

The authors wish to acknowledge the assistance of Diane Langkamp in the preparation of this manuscript.

\section{References}

1. Hirsch, H. A. and Finland, M.: Effect of food on the absorption of erythromycin propionate, erythromycin stearate and triacetyloleandomycin. Am. J. Med. Soi. 237:693 (1959).

2. Blough, H. A., Hall, W. H., and Hong, L.: Serum levels and clinical results with erythromycin propionate. Amer. J. Med. Sci. 239:539 (1960).

3. Clapper, W. E., Mostyn, M., and Meade, G. H.: An evaluation of erythromycin stearate and propionyl erythromycin in normal and hospitalized subjects. Antibiot. Med. Clin. Therap. 7:91 (1960).

4. Quinn, E. L., Colville, J. M., and Cox, F.: Comparative studies of erythromycin propionate, erythromycin stearate, and triacetyloleandomycin. Antibiotic. Med. Clin. Therap. 7:103 (1968).

5. Hall, G. A., Roberts, C. E., Perry, D. M., and Kirby, W.M.M.: Erythromycin stearate and propionyl erythromycin: A comparison of blood levels obtained after oral administration. Antibiot. Med. Clin. Therap. 7:231 (1960).

6. Perry, D. M., Hall, G. A., and Kirby, W. H. H.: Clinical and laboratory studies of erythromycin propionate. Antibiot. Med. Clin. Therap. 7:320 (1960).

7. Griffith, R. S.: Comparison of antibacterial activity in the sera of subjects ingesting erythromycin and propionyl erythromycin lauryl sulfate. Antimicrob. Agents Anm. 192 (1960).

8. Hirsch, H. A., Pryles, C. V., and Finland, M.: Effect of food on absorption of a new form of erythromycin propionate. Amer. J. Med. Sci. 239:198 (1960).

9. Griffith, R. S. and Black, H. R.: A comparison of blood levels after oral administration of erythromycin and erythromycin estolate. Antibiotics and Chemother. $12: 398$ (1962).

The Journal of Clinical Pharmacolog 
10. Griffith, R. S. and Black, H. R.: Comparison of the blood levels obtained after single and multiple doses of erythromycin estolate and erythromycin stearate. Amer. J. Med. Sci. 247:69 (1964).

11. Bell, S. and Lake, B.: Crossover blood level studies with erythromycin estolate and a "new" erythromycin. Med. J. Lust. 1:1152 (1967).

12. Bell, S. M.: A comparison of absorption after oral administration of erythromycin estolate and erythromycin stearate. Med. J. Aust. 2:1280 (1971).

13. Neaverson, M. A.: Erythromycin estolate. Med. J. Aust. 1:741-742 (1968).

14. Stephens, V. C., Pugh, C. T., Davis, N. E., Hoehn, M. M., Ralston, 8., Sparks, M. C., and Thomkins, L.: A study of the behavior of propionyl erythromycin in blood by a new chromatographic method. $J$. Antibiotics 22:551 (1969).

15. Tardrew, P. L., Mas, J. C. H., and Kenney, D.: Antibacterial activity of 2-esters of erythromycin. Appl. Micro. 18:159 (1969).

16. Tserng, K., and Wagner, J. G.: Fluorometric determination of erythromycin and erythromycin propionate in whole blood or plasma and correlation of results with microbiological assay. J. Anat. Chom. $48: 348$ (1976)

17. Scientific Tables Documenta, 6th Ed., Geigy Pharmaceuticals, Div. of CIBA-GeigJ Corp., Ardsley, N.Y. p. 624.

18. Kavanagh, F., and Dennin, L. J.: In Analytical Microbiology, F. Kavanagh, Ed. Academic Prees, New York 1963, p. 289.

19. Grove, D. C., and Randall, W. A.: Amay Methods of Antibiotics: A Laboratory Manual. New York, Medical Encyclopedia, 1955.

20. Weigand, R. G., and Chun, A. H.: Borum Protein Binding of Erythromycin and Erythromycin 2'-Propionate Ester. $J$. Pharm Sci. 61:425 (1972).

21. Bechtol, L. D., Stephens, V. C., Pugh, C. T., Perkal, M. B., and Coletta, P. A.: Erythromycin Esters-Comparative in-Vivo Hydrolysis and Bioavailability. Curr. Therap. Res. 20:610 (1976).

Address reprint requests to: Dr. A. R. DiSanto, The Upjohn Company, Kalamaroo, Mich. 49001. 